\title{
Peningkatan Nilai Tambah Kacang Tangah di Desa Dlemer Kabupaten Bangkalan Melalui Diversifikasi Produk Olahan
}

\author{
Lilis Suaibah , Abdur Rahman ', Rakhmawati \\ Program Studi Ekonomi Syariah Universitas Trunojoyo Madura \\ 2 Program studi Teknik Industri Pertanian Universitas Trunojoyo Madura \\ E-mail : lilissuwaibah12@gmail.com \\ DOI: https://doi.org/10.21107/pangabdhi.v5i2.6107
}

Artikel Diterima : 20 Agustus 2019/ Revisi : 17 September 2019/Terbit : 19 Oktober 2019

\begin{abstract}
Abstrak
Kegiatan KKN Abdimas Universitas Trunojoyo Madura (UTM) Di Desa Dlemer Kabupaten Bangkalan merupakan salah satu bentuk kegiatan pemberdayaan masyarakat, dengan tujuan meningkatkan potensi desa dan daya saing, serta memberikan nilai tambah kacang tanah menjadi produk yang memiliki nilai ekonomis lebih tinggi. Artikel ini bertujuan (1) mendeskripsikan capaian program kegiatan KKN Abdimas di Desa Dlemer; (2) mendeskripsikan penerapkan teknologi pengolahan kacang tanah, dan (3) mendeskripsikan nilai tambah produk sambal pecel dan ting-ting kacang. Kelompok sasaran program KKN Abdimas ini adalah masyarakat dan ibu-ibu PKK Desa Dlemer. Pendamping program dalam kegiatan ini adalah mahasiswa kelompok 43 pada kegiatan KKN UTM tahun 2019. Metode penelitian yang digunakan adalah kaji tindak partisipatif. Pemaparan hasil kegiatan KKN Abdimas dan analisis data penelitian disajikan secara diskriptif kualitatif. Hasil analisis menunjukkan (1) target capaian kegiatan KKN Abdimas tahun 2019 secara umum tercapai; (2) penerapan teknologi pengolahan kacang tanah dengan menggunakan mesin oven dan mesin penggiling mampu meningkatkan efisiensi produksi dan kualitas produk sambal pecel dan ting-ting kacang; (3) kegiatan KKN Abdimas di Desa Dlemer mampu memberikan peningkatan nilai tambah kacang tanah menjadi produk yang memiliki nilai ekonomis lebih tinggi, memberikan alternatif usaha baru, dan peningkatan pendapatan usaha masyarakat.
\end{abstract}

Kata kunci: nilai tambah, kacang tanah, PKK, sambal pecel

\section{PENDAHULUAN}

Kacang tanah merupakan komoditas tanaman pangan potensial dan memiliki prospek yang baik untuk dikembangkan, karena memiliki keterkaitan yang kuat antara sektor hulu sampai hilir (Yulifianti et al., 2016). Kacang tanah merupakan komoditas strategis, karena permintaannya cukup besar setiap tahun baik untuk pangan, pakan, maupun industri. Beragam olahan produk berbahan baku kacang tanah membutuhkan bahan baku yang cukup, baik dari sisi kuantitas maupun kualitas. Rata-rata permintaan kacang tanah tiap tahun \pm sebesar 816 ribu ton (BPS Provinsi Jawa Timur, 2019), sedangkan 638.896 ton $(79,86 \%$ dari kebutuhan nasional). Kekurangannya selama ini dipenuhi dari import.

Sentra komoditas kacang tanah di Madura berada di Kabupaten Bangkalan dan. Di Kabupaten Bangkalan, luas panen musim tanam 2016 sebesar $29.290 \mathrm{Ha}$, dengan produksi 36.067 ton dan produktivitas 12,31 ton/Ha (BPS Kabupaten Bangkalan, 2018). Desa Dlemer Kecamatan Arosbaya merupakan salah satu desa penghasil kacang tanah di Kabupaten Bangkalan.

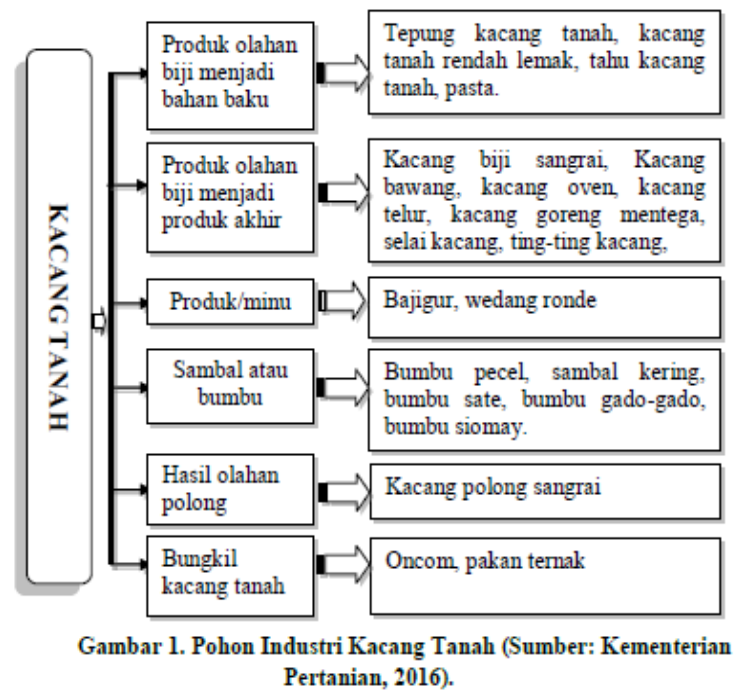


Karakteristik komoditas hasil pertanian adalah bersifat musiman, memakan tempat, dan mudah rusak, sehingga membutuhkan upaya penanganan pasca panen dan teknologi pengolahan yang tepat. Pengolahan kacang tanah menjadi produk olahan industri pangan merupakan salah satu upaya peningkatan nilai tambah dan mendukung program diversifikasi pangan (Yulifianti et al., 2016).

Sebagian besar kacang tanah dijual di Desa Dlemer dalam bentuk komoditas. Penanganan pasca panen yang dilakukan oleh petani diantaranya adalah pencucian, pengeringan, dan penggudangan. Belum banyak masyarakat yang melakukan pengolahan menjadi beraneka macam produk yang mempunyai nilai ekonomis lebih tinggi dibanding dijual dalam bentuk komoditas. Ada beberapa rumah tangga yang melakukan pengolahan kacang tanah menjadi sambal pecel, namun masih dalam skala kecil dan menggunakan teknologi produksi yang konvensional sehingga kualitas produk rendah dan jangkauan pasar terbatas di wilayah Desa Dlemer.

Penerapan teknologi pengolahan kacang tanah dengan teknik penyangraian atau pengovenan merupakan salah satu penerapan IPTEKS yang bisa dilakukan untuk mengatasi permasalahan agroindustri bernbasis kacang tanah (Wijayanti. N., dan Purwatiningrum. I., 2016). Teknik ini selain efisen, juga mampu menurunkan kandungan lemak dan kalori yang ada di kacang tanah. Persentase penurunan minyak sekitar 20,2\% dan kenaikan protein sebesar 9-10\% (Yulifianti et al., 2016). Teknologi tepat guna yang lainnya untuk meningkatkan nilai tambah kacang tanah adalah penggunaan mesin penggiling yang berfungsi untuk pembuatan produk berbentuk sambal, bumbu, pasta, dan tingting kacang.

Biji kacang tanah mudah terkontaminasi aflaktosin, yang merupakan hasil metabolisme skunder jamur Aspergillus flavus, Aspergillus parasiticus, dan Aspergillus nomius, sehingga perlu penganganan lebih lanjut agar bisa tahan lama selama proses distribusi dan penyimpanan (Rahmianna dkk., 2007). Menurut Yaz danpanah et al., 2005, proses penyangraian dapat menurunkan resiko aflaktosin pada sambal pecel.

Melalui Tridharma Perguruan Tinggi, Universitas Trunojoyo Madura (UTM) bisa memberikan kontribusi keilmuan, penelitian dan pengabdian pada masyarakat dengan menerapkan IPTEKS yang berupa teknologi tepat guna yang sesuai dengan kebutuhan masyarakat. Kegiatan Kuliah Kerja Nyata Pengabdian Masyarakat (KKN Abdimas), merupakan kegiatan yang strategis untuk mentransfer IPTEKS yang dihasilkan oleh civitas akademika UTM ke tengah- tengah masyararakat.

Berdasarkan latar belakang di atas, maka tujuan KKN Abdimas ini adalah:

1. Mendeskripsikan capaian program pendampingan masyarakat Desa Dlemer melalui kegiatan KKN Abdimas tahun 2019.

2. Mendeskripsikan penerapkan teknologi pengolahan kacang tanah menjadi sambal pecel dan ting-ting kacang dengan menggunakan mesin oven dan mesin penggiling.

3. Mendeskripsikan nilai tambah produk sambal pecel dan ting-ting kacang.

\section{METODE}

\section{Lokasi dan Partisipan}

Lokasi KKN Abdimas di Desa Dlemer Kecamatan Arosbaya Kabupaten BangkalanMadura. Kelompok sasaran utama adalah kelompok Pembinaan Kesejahteraan Keluarga (PKK) Desa Dlemer. Pelaksana kegiatan ini adalah tim KKN Abdimas UTM, dan dibantu oleh tenaga pendamping yang merupakan nbmahasiswa KKN UTM kelompok 43. Sedangkan partisipan dalam program ini adalah ibu-ibu PKK Dusun Dlemer dan Dusun Ronceh Desa Dlemer.

\section{Bahan dan Alat}

Bahan baku untuk membuat sambal pecel meliputi: kacang tanah, cabai merah, cabai rawit, bawang putih, kencur, daun jeruk purut, gula merah, asam jawa, jeruk purut, dan garam. Sedangkan bahan baku untuk membuat ting-ting kacang adalah gula pasir, kacang tanah, wijen, dan mentega. Peralatan yang digunakan meliputi: oven, kompor gas, mesin penggiling, wajan, pisau, baskom, tempayan, telenan, cobek, spatula atau sutil, pemipih, gelas ukur, timbangan digital, cetakan, plastik, dan pengemasan produk.

\section{Prosedur Kegiatan KKN Abdimas}

Tahapan pelaksanaan kegiatan terdiri dari:

1. Tahapan persiapan meliputi: penyusunan proposal KKN Abdimas, sosialisasi program, diskusi dan penyusunan program $\mathrm{KKN}-$ Abdimas dengan mahasiswa KKN, serta Survei lokasi dan Rapid Rural Appraisal (RRA) dan Participatory rural appraisal (PRA). 
2. Tahapan pelaksanaan program meliputi: (a) pelatihan produksi sambal pecel, (b) pelatihan produksi ting-ting kacang (c) pelatihan pengemasan produk (d) pelatihan pemasaran (e) pendampingan opesaional mesin produksi (f) penyerahan prototype mesin oven dan mesin penggiling kacang, dan (g) pendampingan berkelanjutan.

Tujuan dilakukan RRA adalah untuk melibatkan masyarakat sasaran agar muncul keinginan perubahan secra mandiri, dan mendorong kesadaran kritis masyarakat lainnya (Lestari. D., dan Sururi, 2016). Tujuan RRA agar masyarakat desa dapat menganalisis pengetahuan mereka tentang kondisi dan kehidupan desa, serta membuat rencana dan tindakan nyata (COREMAP \& Departemen Perikanan dan Kelautan, 2016).

\section{Metode Analisis}

Metode penelitian yang digunakan adalah kaji tindak partisipatif. Pemaparan hasil pendampingan dan pemberdayaan masyarakat serta analisis data penelitian disajikan secara diskriptif kualitatif.

\section{HASIL DAN PEMBAHASAN}

\section{Capaian program Kegiatan KKN Abdimas}

Capaian dalam kegiatan KKN Abdimas disajikan pada tabel berikut.

Tabel 1. Target Capaian dan Indikator Capaian Kegiatan KKN Abdimas

\begin{tabular}{|c|c|c|}
\hline No & Capaian & Indikator Capaian \\
\hline 1. & $\begin{array}{l}\text { Peningkatan } \\
\text { pengetahuan kelompok } \\
\text { sasaran (PKK Desa } \\
\text { Dlemer) }\end{array}$ & $\begin{array}{l}\text { a. Peningkatan pengetahuan kelompok } \\
\text { sasaran tentang teknologi produksi } \\
\text { pengolahan kacang tanah menjadi produk } \\
\text { olahan sambal pecel dan ting-ting kacang. } \\
\text { b. Peningkatan manajemen usaha dan } \\
\text { manajemen keuangan. } \\
\text { c. Peningkatan ketrampilan kelompok sasaran } \\
\text { dalam hal pemasaran online. }\end{array}$ \\
\hline 2. & $\begin{array}{l}\text { Peningkatan produksi } \\
\text { usaha kecil pengolahan } \\
\text { berbahan baku kacang } \\
\text { tanah }\end{array}$ & $\begin{array}{l}\text { Peningkatan kapasitas dan kualitas produksi } \\
\text { sambal pecel dan ting-ting kacang, karena } \\
\text { penggunan mesin produksi yang lebih modern. }\end{array}$ \\
\hline 3. & $\begin{array}{l}\text { Perbaikan sitem } \\
\text { produksi }\end{array}$ & $\begin{array}{l}\text { Perbaikan sistem produksi dari manual } \\
\text { menjadi menggunakan mesin produksi yg lebih } \\
\text { efisien. }\end{array}$ \\
\hline 3. & $\begin{array}{l}\text { Penambahan alat } \\
\text { produksi }\end{array}$ & $\begin{array}{l}\text { PKK Desa Dlemer memiliki asset } 1 \text { unit oven } \\
\text { gas, } 1 \text { unit mesin penggiling kacang, dan } \\
\text { beberapa peralatan produksi kacang tanah. }\end{array}$ \\
\hline
\end{tabular}

Tabel 2. Dampak Program KKN Abdimas terhadap Produksi Sambal Pecel

\begin{tabular}{|c|c|c|}
\hline \multirow{3}{*}{ somponen } & \multicolumn{2}{|c|}{ Sambal Pecel } \\
\hline & Sebelum KKN & sesudah KKN \\
\hline & Abdimas & Abdimas \\
\hline 1. Beban pekerjaan & - Lebih berat & - Lebih ringan \\
\hline $\begin{array}{l}\text { 2. Lama proses (efelktifitas } \\
\text { proses }\end{array}$ & - $10 \mathrm{~kg}=120$ menit & $-\underline{10 \mathrm{~kg}}=60$ menit \\
\hline $\begin{array}{l}\text { 3. Masa badaluwarsa } \\
\text { (expired time) }\end{array}$ & - 1 bulan & - 3 bulan \\
\hline 4. Kapasitas produlksi & - $5 \mathrm{~kg} / \mathrm{hari}$ & - $13 \mathrm{~kg} / \mathrm{hari}$ \\
\hline 5. Luas pemasaran & - 1 desa (Dlemer) & $\begin{array}{l}\text {-3 Desa (Dlemer. } \\
\text { Arrosbaya } \\
\text { Tambegan) }\end{array}$ \\
\hline 6. Kemasan & - Kurang menarik & - Lebih menarik \\
\hline 7. Label & - Tanpa label & $\begin{array}{l}\text { - Memiliki label dan } \\
\text { merk. }\end{array}$ \\
\hline
\end{tabular}

Sebelum kegiatan KKN Abdimas, kelompok sasaran belum memiliki pengetahuan tentang cara pembuatan ting-ting kacang. Melalui kegiatan pelatihan produksi, PKK Desa Dlemer memiliki ketrampilan membuat produk ting-ting kacang. Berikut foto produk olahan kacang tanah PKK Desa Dlemer.

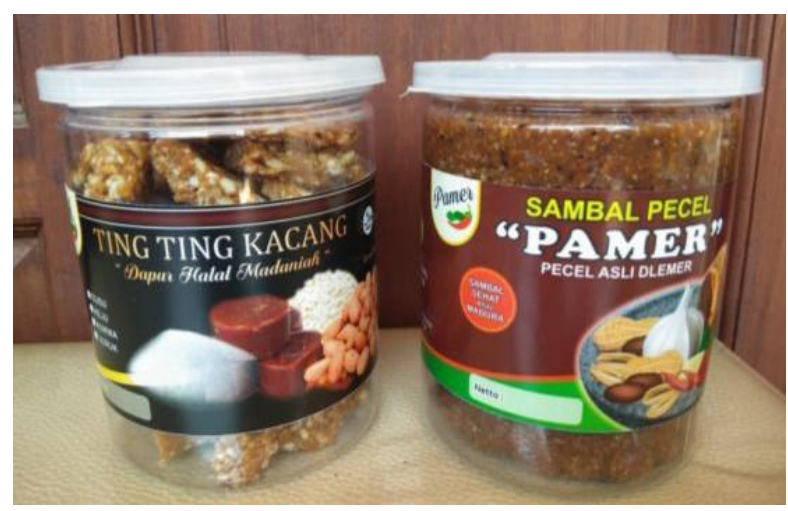

Gambar 1. Sambal Pecel dan Ting-Ting Kacang Tanah

\section{Penerapan Teknologi Pengolahan Kacang Tanah}

Penerapan mesin oven dalam produksi sambal pecel dan ting-ting kacang mampu mengefektifkan proses pengolahan. Intensitas waktu yang dibutuhkan menyangrai kacang tanah secara manual membutuhkan waktu proses selama 2 jam per proses produksi. Namun, jika menggunakan mesin oven relatif lebih cepat, yaitu selama 1 jam per proses produksi atau lebih efisien sebesar $50 \%$. Disamping itu tingkat kematangan kacang tanah lebih merata jika diproses dengan mesin oven. Penggunaan mesin penggiling mampu mempercepat proses produksi hingga $100 \%$ lebih cepat dibandingkan penggilingan secara konvensional.

Berikut foto mesin oven dan mesin penggiling yang diimplementasikan dalam produksi sambal pecel dan ting-ting kacang pada program KKN Abdimas.
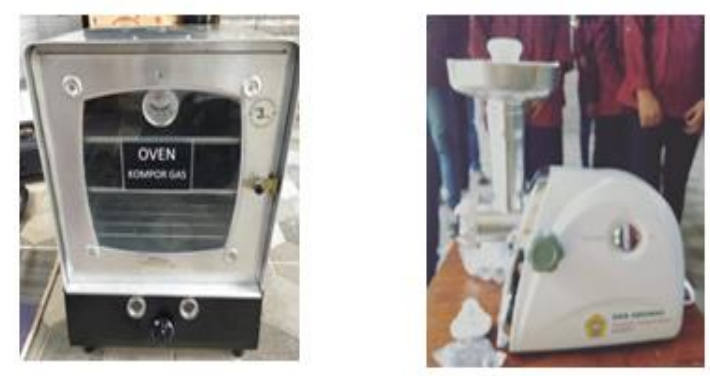

Gambar 2. Oven Kompor Gas dan Mesin Penggiling Kacang

\section{Pelatihan Pembuatan Sambal Pecel}

Pelatihan pembuatan sambal pecel dilakukan oleh tim KKN Abdimas dengan mendatangkan 
pemateri yang berasal dari pengusaha sambal pecel, yaitu home industri sambal pecel "Nyampleng" yang berlokasi di Kecamatan Ketapang Kabupaten Sampang.
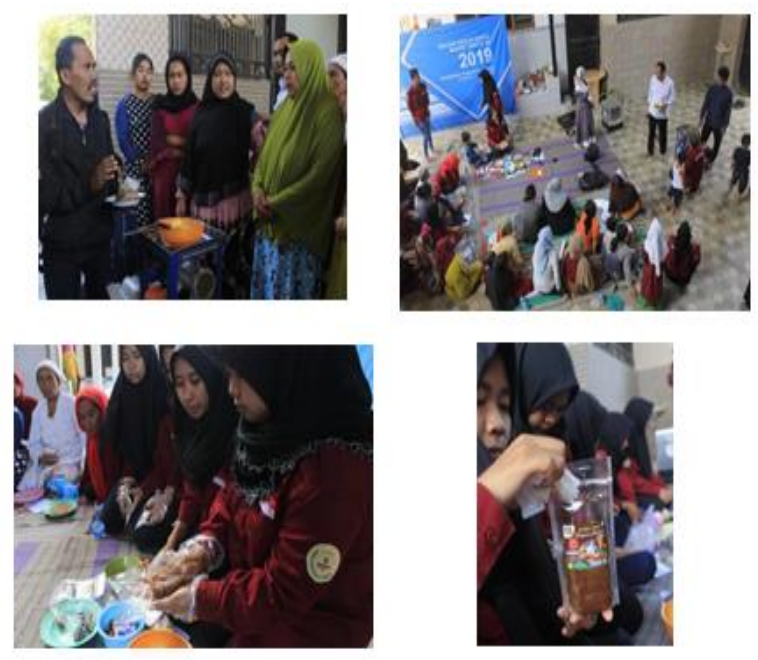

Gambar 3. Pelatihan Produksi dan Pengemasan

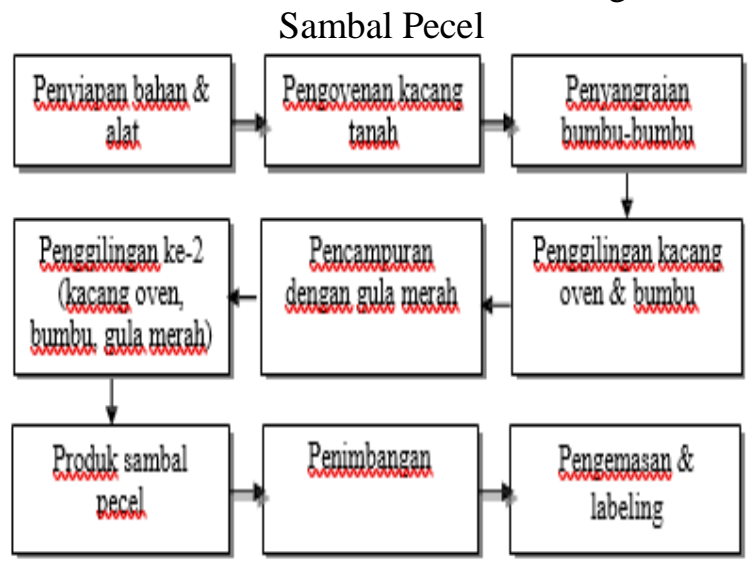

Gambar 4. Proses Produksi Sambel Pecel

Komposisi bahan baku sambal pecel PKK Desa Dlemer terdiri dari kacang tanah $1 \mathrm{~kg}$, cabai merah 100 gr, cabai rawit 100 gr, bawang putih 100 gr, kencur 50 gr, daun jeruk purut 6 lembar, gula merah $0,5 \mathrm{~kg}$, asam jawa 0,5 , jeruk purut secukupnya, dan garam secukupnya (Suaibah et.al., 2019).

Kelompok sasaran juga diberikan materi tentang keamanan bahan bangan dan teknologi pengemasan oleh tim KKN Abdimas yang kompeten, yaitu dari Program studi Teknologi Industri Pertanian UTM. Fungsi pengemasan adalah untuk menjaga kehigienisan produk (Indrajaya, 2015), meningkatkan performace produk, mencegah udara masuk, mengawetkan bahan pangan, dan melindungi produk dari kerusakan serta mencegah tumbuhnya jamur yang merusak kualitas sambal pecel. Kemasan yang kurang rapat dapat mengakibatkan jamur
Aspergillus flavus tumbuh pada produk bahan makanan (Agnis et.al., 2015). Sambal pecel juga dapat terkontaminasi mikroba, jika dalam proses produksinya tenaga kerja kurang menjaga kebersihan alat-alat yang dipergunakan (Anggreini dan Mediaswanti, 2018).

Sebaiknya untuk proses produksi sambal pecel tenaga kerja menggunkan sarung plastik agar produk yang dihasilkan terjaga kehigienisannya. Kemasan dan labeling juga dapat berfungsi sebagai strategi promosi produk sambal pecel, agar konsumen lebih mengenali produk sambal pecel yang diproduksi oleh PKK Desa Dlemer. Dengan desain kemasan yang menarik, konsumen akan terfokus pada produk dalam timbunan berbagai produk disekelilingnya (Uchyani et.al., 2016).

\section{Pelatihan Pembuatan Ting-Ting Kacang}

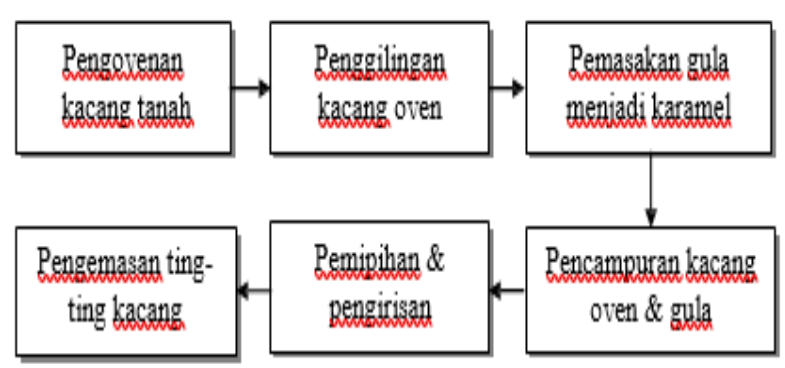

Gambar 5. Proses Produksi Ting-Ting Kacang

Pelatihan pembuatan ting-ting kacang oleh tim KKN Abdimas dilakukan dengan tujuan untuk mengenalkan teknologi sederhana dalam pengolahan kacang tanah. Ketrampilan ini bisa dijadikan alternatif usaha kecil dan menambah diversifikasi produk PKK Desa Dlemer. Bahan baku untuk membuat ting-ting kacang adalah gula pasir 200 gr, kacang tanah 250 gr, wijen secukupnya, dan mentega 1 sendok makan.
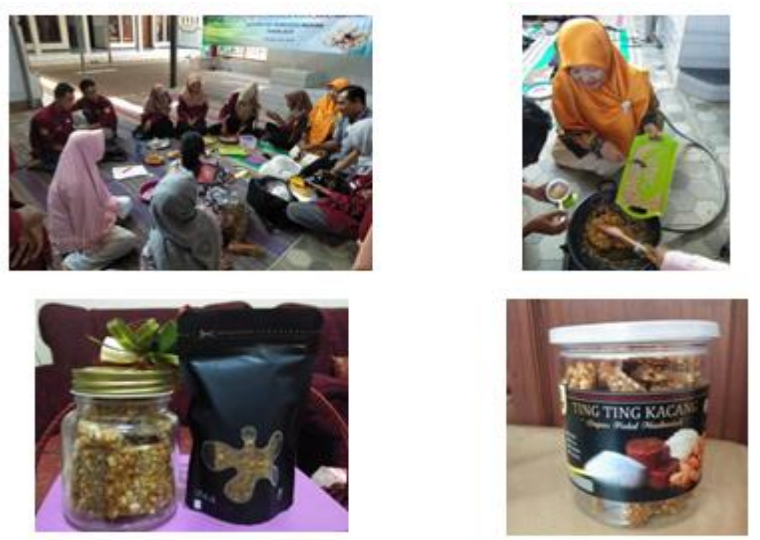

Gambar 8. Pelatihan Produksi Ting-Ting 


\section{Pelatihan Manajemen dan Analisa Usaha}

Pelatihan manajemen dan analisa usaha diberikan oleh tim KKN Abdimas dan pemateri dari dosen Program Studi Agribisnis UTM. Materi pelatihan diantaranya tentang analisa kelayakan usaha, penentuan harga jual, administrasi keuangan, pembukuan usaha kecil, dan strategi pemasaran.

Tabel 3. Analisa Kelayakan Usaha Sambal Pecel dan Ting-Ting Kacang Per Periode Produksi (Per 1 Bulan)

\begin{tabular}{|c|c|c|}
\hline \multirow[t]{2}{*}{ Uraian } & \multicolumn{2}{|c|}{ Braduk } \\
\hline & Sambal Pecel & Ting-Ting \\
\hline Biaxa tetap (Rp) & 78.000 & 40.000 \\
\hline Biaya variabel ( $R p)$ & 15.522 .000 & 3.391 .500 \\
\hline Total biaxa $(\mathrm{Rp})$ & 15.600 .000 & 3.431 .500 \\
\hline Jumlah produdssi & $390 \mathrm{~kg}$ & 300 bungkus \\
\hline Harrga jual & Rp. $50.000 / \mathrm{kg}$ & Rp. $15.000 /$ bunglous \\
\hline Renerimaan ( $R p)$ & 19.500 .000 & 4.500 .000 \\
\hline Pendapatan ysaha $(R p)$ & 3.900 .000 & 1.068 .500 \\
\hline $\mathrm{R} / \mathrm{C}$ ratio & 1,25 & 1,31 \\
\hline
\end{tabular}

Dari kriteria investasi kedua produk PKK Desa Dlemer layak untuk dikembangkan, karena memiliki nilai $\mathrm{R} / \mathrm{C}$ ratio lebih besar dari 1 . Pendapatan usaha sambal pecel sebesar Rp.3.900.000/bulan lebih tinggi dibanding tingting kacang yang nilainya sebesar Rp.1.068.500/bulan. Namun, keduanya memberikan konstribusi positif terhadap pendapatan usaha PKK Desa Dlemer.

\section{KESIMPULAN}

1. Target capaian kegiatan KKN Abdimas tahun 2019 secara umum tercapai, ditunjukkan dengan (1) peningkatan pengetahuan dan ketrampilan PKK Desa Dlemer dalam mengolah kacang tanah menjadi sambal pecel dan ting-ting kacang yang berkualitas dan sesuai dengan standar produksi UMKM dan keamanan bahan pangan (2) peningkatan kemampuan PKK Desa Dlemer mengoperasikan mesin oven dan penggiling (3) peingkatan pengetahuan PKK Desa Dlemer tentang manajemen bisnis, analisa kelayakan usaha, dan pemasaran produk.

2. Penerapkan teknologi pengolahan kacang tanah menjadi sambal pecel dan ting-ting kacang dengan menggunakan mesin oven dan mesin penggiling mampu meningkatkan efisiensi produksi dan kualitas produk.

3. Pendampingan dan pemberdayaan masyarakat melalui kegiatan KKN Abdimas di Desa Dlemer mampu memberikan peningkatan nilai tambah kacang tanah menjadi produk yang memiliki nilai ekonomis lebih tinggi, memberikan alternatif usaha baru bagi PKK Desa Dlemer, dan peningkatan pendapatan usaha masyarakat.

\section{DAFTAR PUSTAKA}

Agnis, F.R, et.al.. 2015. Gambaran Jamur Aspergillus Flavus pada Bumbu Pecel Instan dalam Kemesan Tanpa Merk yang Dijual pada Pasar Gedong Tataan Kabupaten Pesawaran. Jurnal Analis Kesehatan Vol 4 (2). 10-18 pp.

Anggraini, S.P.A \& Mediaswanti, K.A. 2018. Peningkatan Nilai Produktivitas Usaha Bumbu Pecel Menggunakan Alat Sangrai Otomatis. JAST: Jurnal Aplikasi Sains dan Teknologi. Vol 2 (2). 68 -73 pp.

Badan Pusat Statistik Kabupaten Bangkalan, 2018. Kabupaten Bangkalan dalam Angka Tahun 2018. https://bangkalankab.bps.go.id. diunduh tanggal 2 April 2019.

Badan Pusat Statistik Provinsi Jawa Timur, 2019. Produksi Kacang Tanah di Jawa Timur Tahun 2007-2017.

https://jatim.bps.go.id/statictable/2018/10/29/1 330/produksi-kacang-tanah- menurutkabupaten-kota-di-jawa-timur-ton-20072017.html. diunduh tanggal 2 April 2019.

COREMAP. 2016. Panduan Pengambilan Data dengan Metode Rapid Rural Appraisal (RRA) dan Participatory Rural Appraisal (PRA). Bina Marina Nusantra. Jakarta

Indrajaya Y.C. 2015. Perancangan Desain Kemasan Sambal Pecel Bumbu Deso Blitar. Surabaya.

Kementerian Pertanian. 2016. Petunjuk Teknis Pengelolaan Kacang Tanah dan Kacang Hijau 2016. Kementerian Pertanian Direktorat Jenderal Tanaman Pangan.

Lestari, D \& Sururi. 2016. Analisis Program Dikat Participatory Rural Appraisal (PRA). Jurnal Administrasi Pendidikan. Vol 13(1).

Rahmianna A.A., Ginting E \& Yusnawan E. 2007. Cemaran Aflatoksin B1 pada Kacang Tanah yang Diperdagangkan di Sentra Produksi Banjarnegara. Penelitian Pertanian Tanaman Pangan. Vol 26 (2): 172-144 pp.

Suaibah L., Rahman A \& Rakhmawati. 2019. Pendampingan Usaha Sambal Pecel Di 
Desa Dlemer Kecamatan Arosbaya Kabupaten Bangkalan. Prosiding Temu Ilmiah dan Seminar Nasional Balitbang Provinsi Jawa Timur, 3-5 September 2019.

Uchyani R. 2016. Pengembangan Pasar Produk Olahan Kacang Melalui Perbaikan Kemasan. Asian Journal of Innovation and Enterpreneurship. Vol 1(1). 12-19 pp.

Yazdanpanah H., Mohammadi, T., Abouhossain
G \& Cheraghali M. 2005. Effect of Roasting on Degradation of Aflatoxins in Contaminated Pistachio Nuts. Food and Chemical Toxicology. Vol 43 (7). 1135-1139 pp.

Yulifiant. R., Santosa. B.A.S., dan Widowati. S., 2016. Teknologi Pengolahan dan Produk Olahan Kacang Tanah. Monograf Balitkabi No. 13: 379-393. 